DOI: https://doi.org/10.35387/ucj.2(4).2021.55-61

\title{
NADIYA TYMKIV
}

\section{INTERDISCIPLINARITY IN THE PROFESSIONAL TRAINING OF FUTURE ENGINEERS}

\begin{abstract}
The article reveals the interconnection of economic, scientific and technical factors in engineering training. The article explores that global enhanced interdisciplinarity has been discussed in the engineering education context from the early 21st century. It has been found out that there is no disagreement about its importance for the engineers, the key question has been how to implement theory into practice both in the curriculum and in the actual learning enhancement phase. Interdisciplinarity in the engineering education is considered as a basis for critically new competitive engineering solutions. The indicators proving the availability of interdisciplinary management system at a higher educational institution are outlined. The necessity of using interdisciplinary educational technologies in the process of training engineers has been substantiated in the article. The decisive significant feature of interdisciplinarity in education under the condition of sharp growth in information activity and the increased role of intellectual property items in modern economy are demonstrated. Interdisciplinarity is based on the network relations among the studied disciplines. Goal, content, and trends in interdisciplinarity are presented in the system of engineering training. It has been claimed that interdisciplinarity, which envisages systemic integration of acquired knowledge into the individual's worldview, enables to transform abstract information into applicable skills and competencies. Interdisciplinary tasks of engineering education boost intensive international collaboration and intercultural cooperation. It is concluded that the interdisciplinarity of the educational process should be focused on the development of human consciousness and the level of moral, socio-economic, professional competencies. It is shown that the transition to interdisciplinary education is a problem of values, rational will and choice.
\end{abstract}

Key words: interdisciplinarity, engineering education, interdisciplinary process, professional competences, professional training, self-education.

\section{МІЖДИСЦИПЛІНАРНІСТЬ У ПРОФЕСІЙНІЙ ПІДГОТОВЦІ МАЙБУТНІХ ІНЖЕНЕРІВ}

Анотація. У статті розглядаються основні аспекти взаємодії науково-технічних та економічних чинників, які враховуються при підготовці інженерів. Визначено, що глобально зумовлена міждисциплінарність обговорюється в контексті інженерної освіти з початку ХХІ століття. Виявлено, що світова спільнота переконана у важливості міждисциплінарності для інженерів, основне питання полягає в тому, як застосувати теорію на практиці при розробці навчальних планів освітніх програм і безпосередньо в процесі навчання. Міждисциплінарність в інженерній підготовці представлена, як база для отримання принципово нових конкурентоспроможних інженерних рішень. Розглянуто ознаки, що вказують на наявність системи управління міждисциплінарністю у закладі вищої освіти. У статті обгрунтовується необхідність застосування міждисциплінарних освітніх технологій у процесі підготовки інженерів. Показана важливість міждисциплінарності освіти в умовах різкого росту інформаційної активності та зростання ролі об'єктів інтелектуальної власності в сучасній економіці. Міждисциплінарність освіти грунтується на мережевих взаємовідношеннях виучуваних дисциплін. Наведено мету, зміст, спрямованість міждисциплінарності освіти в системі підготовки інженерів. Зазначено, що міждисциплінарність, яка передбачає системну інтеграцію знань в картину світу особистості, уможливлює переведення абстрактної інформації на рівень умінь і компетенцій. Міждисциплінарність завдань, які стоять перед інженерною освітою, сприяють активній міжнародній співпраці та міжкультурній взаємодії. Зроблено висновок про те, що міждисциплінарність навчального процесу має бути орієнтована на розвиток свідомості людини й рівень моральних, соціально-економічних, професійних компетенцій. Показано, що перехід до міждисциплінарності освіти -це проблема цінностей, раціональної волі та вибору.

Ключові слова: міждисциплінарність, інженерна освіта, міждисциплінарний процес, професійні компетенції, професійна підготовка, самоосвіта.

Introduction. The world economy in which engineers operate is constantly being transformed and evolutionised. Nowadays the demand for future specialists comprise both profound technical knowledge and awareness how to apply it to specific branch problems. That is why engineering education needs to overcome the barriers of the academic world and be connected with the certain branch industry. It is well known that the appropriate experience that future engineers have to possess arises from the industry. The quality of human capital 
largely depends on such important characteristics as education of the population and its willingness to change in accord with changing conditions of external and internal environment. Global issues of the modern world, for instance, globalization, demographic situation, competition for resources, climate change and so on become powerful drivers for development of new trends in the social, economic, technical and political spheres. One of such trends in science, technology and education is interdisciplinarity, that can be regarded as the principle of organizing scientific knowledge, which gives wide possibilities of the interaction of many disciplines in resolving complex and complicated issues of a society.

As a matter of fact, a society of competitive structure needs personnel ready and capable of inventory, innovative, managerial and rationalization activity, possessing interdisciplinary knowledge and tools of generating a reliable and effective solution with high level of novelty (engineering education), innovativeness (social and commercial efficiency), reliability and responsibility, and strategies in development of invention «resource» in the professional petroleum sphere. In this case, interdisciplinarity is a presentation of definite disciplines, their structures, and contents, specific methods at the level of integration (general unity) as a structuring single, particular, general one based on integration of semantic and axiological criteria. The basis of learning process in terms of interdisciplinarity is not in opposition of definite disciplines, but in their substantiation and interconnection of content, methods, etc. Interdisciplinarity is not a reflection of subjects or methods by science; it is inclusion of knowledge of subjects and methods of every science into unitedintegrated scientific world image. This integration requires system incorporation on the basis of common methods and tasks.

Professional knowledge is constantly highly focused. With the increasing scope of knowledge, this fact seems to be rather natural. It means that the problems related to highlyspecialized knowledge would be solved by standing out them from a wider context, even by separating them from general context. It is obvious that such an approach would never lead to comprehensive solutions which rest on the interdisciplinarity. Traditionally, engineering education is based on the knowledge of physics, chemistry and mathematics. However, there are certain limitations in engineering evolution from an exclusively technical viewpoint (Tarvainen, 2006).

Modern engineers are professionals whose activity directly influences the technological infrastructure of a society. The features that a modern engineer must have given in National Guidelines for Engineering Education (2011). They are the following: an engineer should be able to use both analytical and creative skills to solve socially valuable technological problems; work innovatively, structurally, and diligently; analyze, generate solutions, assess, determine, execute, and report. As we can see an engineer should be a good entrepreneur. Besides, linguistic skills are of great importance, both written and oral, including in foreign languages. Interacting systems are essential to the modern society, and engineers must be skilled at working independently as well as in teams with engineers from your discipline and from others, professionals from other fields, and in interdisciplinary teams. Also, engineers have ethical and environmental responsibilities and a significant impact on a society.

The aim of the study is to present chronological stages in the development of interdisciplinary theory; to concentrate on modifications, application, testing, and vetting of «A Theory of Interdisciplinary Studies»; to focus on the anticipated impact on interdisciplinary theory of enlarged conceptions of interdisciplinarity, such as those espoused by often European scientists in engineering training.

Theoretical basis and methods of research. The issue of interdisciplinarity has been attracting attention for a long period of time. Having performed theoretical analysis of relevant scientific literature we concluded that scholars all over the world had tried to study the impact of interdisciplinarity on future engineers' training. For instance, L. Brown, A. Chan, G. Codner, J. Fishbein, J. Klein, A. Levine, A. Lidgett, W. Mayville, E. McGrath, R. Meeth, C. Nair, W. Newell, A. Patil, A. Repko, A. Russell, M.Tarvainen, N. Walker, T. Williams and others have elaborated research into the use of interdisciplinarity, analyzed the changes occurring within higher education systems in the context of interdisciplinarity. A detailed analysis of the common terminology in this area can be found in studies completed by L. Ackoff, T. Ausburg, 
J. Borland, W. Green, H. Jacobs, L. Lattuca, S. Maasen, J. Moran, N. Nychkalo, and others as well as in the proceedings of international conferences held in recent decades, including those held under UNESCO auspices.

The analysis of a great number of Ukrainian and foreign studies concerning the attributes and competencies a graduate engineer should acquire has revealed the importance of interdisciplinarity among the key factors that ensure competitiveness of engineering graduates in labour market.

Results. Nowadays, interdisciplinarity is becoming an integral part of pedagogical, philosophical, psychological, social and other sciences. It is a hotly debated issue in many countries. Interdisciplinarity of learning process includes multidisciplinarity, convergence of knowledge and divergence of opportunities, engineering, technological, social and economic sciences and humanities, spheres of culture and spiritual concepts, in this way having a dialectic and synergetic influence on drastic changes in culture, economy, engineering and technology, spiritual life, promoting development of educational integrative programmes to increase their ideality. Interdisciplinarity of education minimizes the knowledge (methodologization) within one discipline, but, at the same time, discovers it in a new perspective, maximizing it in other disciplines (multidisciplinarity).

Intensive interdisciplinary exploration in the second half of the 20th century has essentially contributed to our understanding of this issue. In the 1970s the term interdisciplinarity or interdisciplinary approach was widely applied, however, the issue itself was not frequently addressed in the relevant research literature. R. Meeth (1978) laid the foundations of «interdisciplinary» and defined it as «an attempt to integrate the contributions of several disciplines to a problem, issue, or theme from life». At about the same time, E. McGrath (1978) corroborated Meeth's definition, and drew his attention to the fact that «the chief purpose of interdisciplinary work is to integrate relevant knowledge around a significant issue».

The initial focus of the Association for Interdisciplinary Studies (AIS) was on a definition for «interdisciplinary studies». The aim was to distance AIS from those who purported to engage in interdisciplinary teaching without integration or those courses tended to reject disciplines rather than to draw on them. At that time, clarifying the issue of interdisciplinary studies was a necessary prerequisite for the development of theory.

In 1979, the professional literature on interdisciplinary studies was quite modest (Mayville, 1978). The term was used widely, but very often in the discussions of higher education reform. Mayville's definition of «interdisciplinary studies» was a bit vague, he stressed on «interaction among two or more different disciplines that should include the idea of intergration of concepts, methodologies, procedures, epistemology, terminology, and data» (Mayville, 1978, p. 2). But it should be noted that the researcher highlighted integration and disciplines. Although, some experts followed the approach favored by the founders of AIS. In particular, R. Meeth (1978) defined «interdisciplinary» (courses and programs) as «attempts to integrate the contributions of several disciplines to a problem, issue, or theme from life», and he explained «integration» as «bringing interdependent parts of knowledge into harmonious relationship» which «involves relating part to part, part to whole, and whole to part» (p. 10). According to E. McGrath (1978), «the chief purpose of interdisciplinary work is to integrate relevant knowledge around a significant issue» (p. 8).

The first published article about interdisciplinarity was «Defining and Teaching Interdisciplinary Studies» by Newell and Green in 1982. They stuck to the point that «interdisciplinary studies» were «inquiries draw critically on two or more disciplines and which lead to an integration of disciplinary insights (Newell, Green, 1982, p. 24). Thus, this definition had two elements; the first, «drawing» was distinct from and necessarily prior to the second, «integrating», which encouraged AIS discussions of the interdisciplinary process that occurred decades later. That understanding was a minority viewpoint when AIS was founded, though it has become widely and prominently, and by no means, universally accepted in higher education of most countries.

Notably, W. Newell (2013), has pointed out that the development of interdisciplinary theory is central to the maturation interdisciplinary studies profession. Without it, the researcher sees little prospect for demonstrating a role for professional interdisciplinarians as the field of interdisciplinary studies becomes increasingly dominated by disciplinarians. At a more opera- 
tional level, the expert is totally convinced we need theory to guide our search for additional best practices and our vetting of them, and for selecting among variants of interdisciplinary definitions and process. The days of ad hoc-ery are past.

By the mid-1990s the AIS conception of interdisciplinarity had become widely accepted. Three key elements from the definitions of Meeth, McGrath, and Newell and Green were added: 1) interdisciplinarity was identified as a process; 2 ) the justification for interdisciplinary studies was identified as breadth or complexity; 3 ) the outcome of interdisciplinary studies was characterized by comprehensiveness.

A decade after the publication of «Advancing Interdisciplinary Studies», a review of recent definitions of «interdisciplinary studies» identified the common elements in what had become an emerging consensus definition. Those are a substantive focus that exceeds the scope of a single perspective, an identifiable process that involves drawing explicitly on the disciplines which provide insights into the specific substantive focus, and integration in order to solve the problem, resolve the issue, address the topic, answer the question, explain the phenomenon, or create a new product.

While such issues continued and will continue to be debated by interdisciplinarians, the definition of «interdisciplinary studies» had been sufficiently developed and elaborated by the start of the new millennium to serve as a basis for the development of interdisciplinary theory.

Undoubtedly, the AIS has made a lot of progress in the last decade in discussing interdisciplinary process, after focusing on definitions and best practices in the previous two decades. But the explosion of activity outside AIS in team science and transdisciplinary approaches to complex real-world problem-solving, especially in the last decade, makes it imperative that we now move quickly to develop interdisciplinary theory so that all suggested definitions, best practices, and process can be reevaluated and expanded as appropriate to contribute to and benefit from these major new interdisciplinary activities. Gradually, educators started the process of moving discussions from definitions to practice. Among the next publications, the works by A. Repko (2011) are the most notable and favorably reviewed. He discussed interdis- ciplinarity extremely interesting, not only within educational context, but also within scientific one. On the whole, when investigating interdisciplinarity, the researchers took into account both educational and scientific factors and extended the theories that already existed to include the new phenomena.

Over the past few years, the interest in and need for curriculum integration has intensified throughout many countries and particularly in Ukraine. The initial profound methodological work to reflect discussions of interdisciplinarity in higher education was «Handbook on the Undergraduate Curriculum» by A. Levine (1978) where the whole chapter was devoted to interdisciplinary studies. The scholar strongly believed that interdisciplinarity is «a process of answering a question, solving a problem, or addressing a topic that is too broad or complex to be dealt with adequately by a single discipline or profession».

The outstanding American researcher H. Jacobs (1989) made a significant contribution to the discussion of interdisciplinarity and interdisciplinary curriculum. The scientist examined various models and approaches to interdisciplinary design for the past fifteen years, and she pointed out two problems in interdisciplinary courses: the potpourri problem and the polarity problem. As for the first problem, $\mathrm{H}$. Jacobs has considered that many units become a sampling of knowledge from each discipline. For instance, if the subject is Ancient Egypt, there will be a bit of history about Ancient Egypt, a bit of literature, a bit of the arts, and so forth. Hirsch (1974) and Bloom (1987) have criticized this approach for its lack of focus. Unlike the disciplines that have an inherent scope and sequence used by curriculum planners, there is no general structure in interdisciplinary work. Curriculum developers themselves must design a content scope and sequence for any interdisciplinary unit or course. The polarity problem is explained in such a way that interdisciplinarity and the discipline fields have been seen as an either/or polarity, which has promoted a range of conflicts. Not only does the curriculum design suffer from a lack of clarity, but real tensions can emerge among educators. Some pedagogues feel highly territorial about their subjects and are threatened as new views of their subject are promoted. There 
is a need, hence, for both interdisciplinary and discipline-field perspectives in design.

To avoid these two problems, effective interdisciplinary programs must meet two criteria. They must have carefully conceived design features: a scope and sequence, a cognitive taxonomy to encourage thinking skills, behavioral indicators of attitudinal change, and a solid evaluation scheme. They must use both discipline-field-based and interdisciplinary experiences for students in the curriculum.

Knowledge is growing at exponential proportions in all areas of study. If you look at one field, such as science, you see the remarkable degree of specialization that has resulted from research and practice. Each area of the curriculum has the blessing and burden of growth. The curriculum planner must wrestle not only with what should be taught but what can be eliminated from the curriculum.

$\mathrm{H}$. Jacobs (1989) is totally convinced that interdisciplinary is a knowledge view and curriculum approach that consciously applies methodology and language from more than one discipline to examine a central theme, issue, problem, topic, or experience. In contrast to a discipline-field based view of knowledge, interdisciplinarity does not stress delineations but linkages. Meeth (1978) notes that the emphasis is on deliberately identifying the relationship between disciplines. It is a holistic approach with a tradition in Western thought that comes from Plato's ideal of unity as the highest good in all things. Interdisciplinarity nurtures a different perspective with focus on themes and problems of life experience.

When examining the relationship between fields of knowledge, there is a range of prefixes that connote various nuances. Let's consider the following:

Crossdisciplinary: Viewing one discipline from the perspective of another; for example, the physics of music and the history of math (Meeth, 1978).

Multidisciplinary: The juxtaposition of several disciplines focused on one problem with no direct attempt to integrate (Piaget, 1972; Meeth, 1978).

Pluridisciplinary: The juxtaposition of disciplines assumed to be more or less related; e.g., math and physics, French and Latin (Piaget, 1972).

Transdisciplinary: Beyond the scope of the disciplines; that is, to start with a problem and bring to bear knowledge from the disciplines (Meeth, 1978).

Moreover, it seems essential that decisions regarding the curriculum be made with a deliberate consensus as to the kind of disciplinefield emphasis that will occur; otherwise, there is the tendency toward the potpourri and a confused melee of activities when a team starts producing the classes plans. The goal, thus, is to have informed practitioners.

To put it brief, the concept of interdisciplinarity involves a transdisciplinary perspective as «a way to expand the scientific outlook considering any phenomenon outside the framework of any single scientific discipline» (Patil, 2008). The idea of synthesis and integration of knowledge, that lies in the foundation of this principle probably have more than one millennium already (Chan, 2009, p. 6). Interdisciplinarity provides information knowledge conductivity of educational environment, its transparency, continuity, consistency, and compatibility. In the process of education interdisciplinarity the task is set to develop isomorphism of semantic thinking structures in different disciplines. It contributes to mutual understanding by the experts in different scientific fields and opens the floodgates for metadisciplinarity and transdisciplinarity. S. Maasen (2000) critically defines practiced interdisciplinarity as «inducing some interactions at some intersections of some interfields».

Theoretical knowledge plays a particular role under such conditions providing intellectual technologies and intellectual organizations. It is explained by the fact that information is not creative power if it fails to be meaningful, realized, comprehensive, minimized to theoretical concept, it means that it has not become structural knowledge yet, that is based on methodology. Hence, the major productive force of the modern society becomes a subjective factor depending on level of human development, human thinking, human place and role in social-business system, conditions of interaction with Nature.

Afterwards, there is a necessity, a need for new research and engineering, educational, and social and economic paradigm, new methods, the elements of which are: holistic approach, principle of all-encompassing unity; environmental awareness; harmony in interaction of a human being, machine, object, information, and nature; principle of system synergy, principle of 
refilling; self-organization (self-regulation, selfdiscovery, reflection); systematic thinking; openness (continuity, consistency, commensurability); interactions, but not struggle; ecological and aesthetic and economic principles, eco-design; dialectic synergy of freedom, justice, and responsibility; new consumption and production models; cooperation (solidarity, collaboration, replenishment, respect, tolerance), but not competition; temporal unity (principles of actualization, history, futurism); dialectic and synergy of the unity, whole, and completeness (Shields et al, 2014).

Nevertheless, to achieve this goal, one needs, first of all, interdisciplinarity of learning process focused on human consciousness development and the level of staff's moral, socialeconomic, professional competencies. There is a need for not only professional training of prospective engineers, but also the formation of integral, cultural personalities capable of living in harmony in the world, society, in time and in its entirety.

Conclusions. All things considered, the interdisciplinarity of engineering education is based on network interaction of studied disci- plines. It is pedagogical integration in the complex of natural, engineering, technological, mathematical, social and economic, legal, philosophic, and humanitarian knowledge. Besides, interdisciplinarity of education develops a uniform, integrated, dynamically interactive, recursive-continual, dialectic and synergetic, fractal and holographic existence image and relevant mode of student thinking. Engineering education interdisciplinarity, its content and structure may be referred to the category defining quality of education and personal culture in a digital period. Improvement and extension of education due to its interdisciplinarity introduces the relevant content of invariant part of engineering learning process which is so essential in modern innovative conditions, when one should response to new social challenges, new technologies, and new markets quickly and adequately, making decisions in the unbalanced condition of uncertainty keeping balance of mobility and stability. At the same time, transition to interdisciplinarity of education is neither technological nor conceptual one. It is the problem of values, rational will, and choice.

\section{REFERENCES}

Chan, D. (2009) A global engineer for the global community. Policy Engagement, 1 (2), 4-9.

Jacobs, H.H. (1989). Interdisciplinary Curriculum: Design and Implementation. Alexandria, Va: Association for Supervision and Curriculum Development.

Klein, J.T. (1990). Interdisciplinarity: History, theory, and practice. Detroit, MI: Wayne State University Press.

Lattuca, L.R. (2003). Creating Interdisciplinarity: Grounded Definitions from College and University Faculty. History of Intellectual Culture, 3, 20-26.

Levine, A. (1978). Handbook on the undergraduate curriculum. San Francisco: Jossey-Bass.

Maasen, S. (2000). Inducing Interdisciplinarity: Irresistible Infliction? The Example of a Research Group at the Center for Interdisciplinary Research (ZiF), Bielefeld, Germany. In N. Stehr, \& P. Weingart (Eds.), Practising Interdisciplinarity (pp. 173-193). Toronto, ON, Canada: University of Toronto Press.

Mayville, W. V. (1978). Interdisciplinarity: The mutable paradigm. AAHE/ERIC Higher Education Research Report (Issue 9; P. 1-9). Washington, DC: American Association for Higher Education.

McGrath, E. J. (1978). Interdisciplinary studies: An integration of knowledge and experience. Change: The Magazine of Higher Learning, 10, 6-9.

Meeth, R. (1978) Interdisciplinary studies: A matter of definition. The Magazine of Higher Learning, 10, 7: Report on teaching: 6, 4-17.

National Council for Technological Education (NRT). (2011). National guidelines for engineering education. URL: http://www.uhr.no/documents/Nasjonale retningslinjer for ingeni rutdanning ENGELSK.pdf

Newell, W.H. (2013). The State of the field: Interdisciplinary theory. Issues in Interdisciplinary Studies, 31, 22-43.

Improving College and University Teaching, 30, 23-30.

Patil, A. (2008). Global accreditation for global engineering attributes: A way forward. URL: http://acquire.cqu.edu.au:8080/vital/access/services/Download/cqu:4206/ATTACHMENT01?open=t $\underline{\text { rue }}$

Piaget, J. (1972). The Epistemology of Interdisciplinary Relationships. In L. Apostel (Ed.). Interdisciplinarity: Problems of teaching and research in universities (pp. 127-139). Paris: Organization for Economic Cooperation and Development. 
Repko, A. (2011). Interdisciplinary Research: Process and theory (2nd rev. ed). Los Angeles: SAGE Publ. Inc. Shields, D., Verga, F., \& Blengini, G. A. (2014). Incorporating sustainability in engineering education. Adapting current practices to mining and petroleum engineering education. International Journal of Sustainability in Higher Education, 15 (4), 390-403.

Tarvainen, M. (2006). Engineering education and interdisciplinary studies. URL: http://www.pantaneto.co. uk/issue22/tarvainen.htm

Thorén, H., Persson, J. (2013). The Philosophy of Interdisciplinarity: Sustainability Science and ProblemFeeding. Journal for General Philosophy of Science, 44, 337-355.

Tymkiv, N. (2018). Specific features of forming interdisciplinary teams and designing projects in Petroleum Engineering. Szkoła - Zawód - Praca, 15, 13-21. URL: https://repozytorium.ukw. edu.pl/handle/item/5755

UNESCO. (1998). World declaration on higher education in the twenty-first century: vision and action. Paris: UNESCO House. URL: http://www.unesco.org/cpp/uk/declarations/world.pdf

$\mathrm{Wu}$, Y. (2014). Training mode and mechanisms for the excellent engineers programme. World Transactions on Engineering and Technology Education, 12 (4), 701-705.

Надія Тимків, доктор педагогічних наук, доцент, завідувач кафедри англійської мови ІваноФранківського національного технічного університету нафти і газу.

Nadiya Tymkiv, Doctor of Sciences in Pedagogy, Associate Professor, Head of the English Language Department, Ivano-Frankivsk National Technical University of Oil and Gas.

E-mail: nadia tymkiv@ukr.net ORCID ID 0000-0002-5598-7717

Received: 15.11.2021

Accepted: 29.11.2021 